\title{
Ovulasjonsinduksjon ved bruk av letrozol
}

\begin{abstract}
Sammendrag
Bakgrunn. Klomifensitrat er et førstevalg for ovulasjonsinduksjon av infertile anovulatoriske kvinner. Selv om tablettene fremkaller ovulasjon hos de fleste, vil bare én av fire kvinner etter gjentatte behandlinger oppnå vellykket graviditet. De siste årene har flere klinikker begynt å anvende letrozoltabletter for ovulasjonsinduksjon. I denne artikkelen gis en kort presentasjon av letrozol, virkningsmekanismer forklares og fordeler og ulemper med letrozol sammenliknet med klomifensitrat blir drøftet.
\end{abstract}

Materiale og metode. Artikkelen er basert på mer enn to års erfaring med bruk av letrozol for ovulasjonsinduksjon før coitus eller inseminasjon, i tillegg til bruk av letrozol ved in vitro-fertilisering. Det er dessuten foretatt ikke-systematiske søk i PubMed for å beskrive hva man vet om letrozol når medikamentet benyttes i reproduksjonssammenheng.

Resultater. Letrozol kan øke sjansen for vellykket graviditet og redusere risikoen for flerlinggraviditet sammenliknet med klomifensitrat. Dessuten vil mer enn $60 \%$ av kvinnene som er resistente mot klomifensitrat, kunne ovulere ved hjelp av letrozol. Letrozol i kombinasjon med gonadotropin kan også være gunstig i visse tilfeller ved in vitro-fertilisering.

Fortolkning. Studier av bruk av letrozol i reproduksjonssammenheng har så langt vist lovende resultater. Store randomiserte studier er nødvendig før man kan konkludere om letrozol bør bli førstevalg for ovulasjonsinduksjon.

\section{Erling Ekerhovd}

erling.ekerhovd@obgyn.gu.se

Kvinneklinikken

Førde sentralsjukehus

6807 Førde

og

London Fertility Centre

112A Harley Street

London W1G 7JH

Hos $20-30 \%$ av alle kvinner som søker medisinsk hjelp for ufrivillig barnløshet, diagnostiseres anovulasjon (1). De aller fleste av disse har et normalt østrogennivå. For å indusere eggløsning hos denne pasientgruppen er klomifensitrattabletter førstevalget. Man forsøker derved å fremkalle ovulasjon av ett eller maksimalt to egg rundt det tidspunktet paret enten har coitus eller at det utføres inseminasjon.

Data fra en metaanalyse viser at $46 \%$ av anovulatoriske kvinner som tar én tablett $(50 \mathrm{mg})$ klomifensitrat i fem dager i tidlig follikkelfase, oppnår ovulasjon (2). Ytterligere $21 \%$ av kvinnene vil respondere på behandlingen om man øker dosen til $100 \mathrm{mg}$ daglig. Ved å ordinere maksimaldosen på $150 \mathrm{mg}$ daglig vil totalt $73 \%$ av kvinnene ovulere (3).

Dersom man lykkes i å fremkalle ovulasjon, vil ca. $36 \%$ av kvinnene oppnå graviditet ved gjentatt behandling opptil seks ganger (3). I 10-20\% av tilfellene vil det foreligge flerlinggraviditet, hvorav det i de aller fleste tilfellene vil være tvillinggraviditet (4).

Hos omtrent $20 \%$ av dem som oppnår graviditet etter bruk av klomifensitrat vil graviditeten ende i spontanabort. Dette betyr at drygt en firedel av dem som gjennomgår gjentatte behandlinger med klomifensitrat får sitt ønske om å bli foreldre oppfylt (3).

Den lave graviditetsfrekvensen sammenliknet med antallet ovulasjoner og den relativt høye forekomsten av tidlig spontanabort sammenliknet med kvinner som blir gravide spontant, antas til en vesentlig grad å skyldes medikamentets antiøstrogene effekt på cervixsekretet og endometriet. Klomifensitrat blokkerer østrogenreseptorene i cervix og endometriet. Dette gjør at spermiene kan ha vanskeligheter med å passere cervikalkanalen eller at implantasjonen av det befruktede egget ikke blir optimal fordi endometriet er tynt og lite mottakelig for det befruktede egget (5-7).

Alternativet til klomifensitrat har inntil nylig vært subkutane injeksjoner med follik- kelstimulerende hormon (FSH), eventuelt i kombinasjon med luteiniserende hormon (LH). Injeksjoner med gonadotropin har en gunstig effekt på cervixsekretet og endometriets tykkelse. Imidlertid medfører også denne behandlingsstrategien stor risiko for ovulasjon fra flere follikler. En forekomst av flerlinggraviditet på $15-25 \%$ etter ovarial stimulering med FSH er vanlig (8). For å redusere risikoen for flerlinggraviditet velger man derfor ikke sjelden å utføre in vitrofertilisering.

De senere årene har man ved stadig flere klinikker internasjonalt begynt å bruke aromataseinhibitorer for å stimulere ovariene (9). Denne preparatgruppen har vist seg å ha visse fortrinn sammenliknet med klomifensitrat og FSH. De vanligste aromataseinhibitorene i klinisk bruk er letrozol og anastrozol. For ovulasjonsinduksjon er det spesielt letrozoltabletter som benyttes. Letrozol er imidlertid kun registrert for behandling av brystkreft. Til tross for dette er letrozol et velkjent medikament for ovulasjonsinduksjon, blant annet i Canada, USA og England.

Denne artikkelen beskriver virkningsmekanismer og drøfter fordeler og ulemper med letrozol sammenliknet med klomifensitrat.

\section{Materiale og metode}

Artikkelen er basert på egen klinisk erfaring med bruk av klomifensitrat og letrozol. Dessuten er det foretatt ikke-systematiske søk i PubMed for å gi et innblikk i hva som er publisert om letrozol i reproduksjonssammenheng.

\section{Virkemekanismer}

Både klomifensitrat og letrozol stimulerer eggstokkene ved å øke endogen produksjon av FSH. Klomifensitrat blokkerer kompetitivt østrogenreseptorene først og fremst i hypothalamus, men også i hypofysen (fig 1).

\section{Hovedbudskap}

- Letrozoltabletter kan benyttes for å fremkalle ovulasjon

- Letrozol kan anvendes dersom man ikke oppnår graviditet ved hjelp av klomifensitrat

- Det er ikke påvist teratogen effekt av letrozol når medikamentet brukes til ovulasjonsinduksjon 
I tillegg blokkerer klomifensitrat østrogenreseptorene i cervix og endometriet. Sentralt oppfattes blokkeringen av østrogenreseptorene som om det foreligger østrogenmangel, ettersom den negative tilbakekoblingsmekanismen settes ut av funksjon. Responsen fra hypofysen er økt frigjøring av FSH og LH, noe som stimulerer ovariene slik at follikler begynner å vokse.

Letrozol er en reversibel selektiv aromatasehemmer. Aromatase konverterer androstendion til østron og testosteron til østradiol. Ved å ta 2,5-5 mg letrozol i fem dager fra syklusdag 2 eller 3 blokkeres produksjonen av østrogen samtidig som konsentrasjonen av androgen i eggstokkene øker (fig 2) (10). Det lave nivået av østrogen vil via vanlige tilbakekoblingsmekanismer til hypothalamus og hypofyse stimulere til økt produksjon og frigjøring av FSH, noe som igjen fremmer follikkelvekst. Letrozol har en halveringstid på ca. 45 timer (11). Den korte halveringstiden innebærer at effekten av medikamentet elimineres raskt. Ettersom den normale tilbakekoblingskontrollen er intakt, vil økt nivå av østrogen redusere frigjøringen av FSH i siste halvdel av follikkelfasen. En konsekvens av dette er at den dominerende follikkelen vil vokse videre mens mindre follikler vil gjennomgå atresi. Resultatet blir at man ofte oppnår ovulasjon fra bare én follikkel.

En annen sannsynlig virkningsmekanisme til letrozol er økt follikulær sensitivitet for FSH. Studier på primate ovarier har vist at en forbigående økning av intraovarialt androgennivå som resultat av aratomatasehemmingen fremmer follikkelveksten og østrogensyntesen via å forsterke effekten av FSH (12). Dessuten ser et økt intraovarialt androgennivå ut til å stimulere insulinliknende vekstfaktor-1 (IGF-1), en substans som utøver en synergistisk effekt med FSH når det gjelder å stimulere folliklene (13).

Én hypotese er at den initielle hemmingen i østrogensyntesen ved bruk av letrozol resulterer i en oppregulering av endometriets østrogenreseptorer (14). Økt sensitivitet for østrogen medfører rask vekst av endometriet når produksjonen av østrogen stiger $i$ siste del av follikkelfasen. Den raske veksten av endometriets tykkelse kan ofte verifiseres ved hjelp av vanlig transvaginal ultralyd. Endometriet blir derved tilstrekkelig tykt og mottakelig til at en vellykket implantasjon skal kunne skje.

\section{Historikk}

I reproduksjonssammenheng var det stilt store forventninger til ulike aromatasehemmere. Et stort tilbakeslag kom imidlertid ved det årlige møtet til American Society for Reproductive Medicine i 2005 der en abstraktpresentasjon antydet en potensiell teratogen effekt av letrozol (15). Presentasjonen resulterte i flere medieoppslag. Legemiddelfirmaet som produserer tablettene, sendte ut en pressemelding der de understreket at pre-

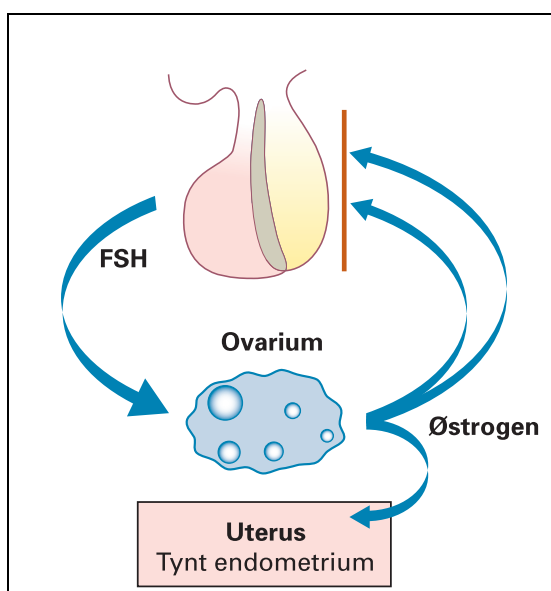

Figur 1 Klomifensitrat blokkerer østrogenreseptorene i hypothalamus og hypofyse i tillegg til $\emptyset$ strogenreseptorene i cervix og i endometriet. Sentralt oppfattes dette som at det foreligger østrogenmangel. Man får derved økt utskilling av follikkelstimulerende hormon (FSH). Dette leder til at flere follikler begynner å vokse i første halvdel av follikkelfasen (a). Follikkelstimulerende hormon vil stimulere produksjonen av østrogen spesielt i den siste halvdel av follikkelfasen (b). Ettersom klomifensitrat har en lang halveringstid på ca. to uker, vil blokkeringen av østrogenreseptorene vedvare. Konsekvensene blir økt risiko for ovulasjon fra flere follikler samtidig som at man har en lav østrogenreseptorpopulasjon i et relativt tynt endometrium ved ovulasjonstidspunktet

paratet var kontraindisert for ovulasjonsinduksjon. Dette førte til at flere leger sluttet å skrive ut letrozol, og flere studier av letrozol i fertilitetssammenheng ble kansellert.

En senere gjennomgang av abstraktet viste at konklusjonen var feilaktig (16). En kanadisk studie har senere avkreftet at det er $ø$ kt risiko for medfødte misdannelser ved bruk av letrozol for å fremme ovulasjon (17). Skal et medikament ha teratogen ef-

fekt, må det være til stede under organogenesen (18). Siden letrozol har kort halveringstid, vil medikamentet være ute av kroppen ved implantasjonstidspunket slik det benyttes for ovarial stimulering (19).

Dyreeksperimentelle studier har derimot vist at bruk av letrozol under graviditet øker risikoen for misdannelser $(20,21)$. På grunn av dette sendte Food and Drug Administration i USA ut en advarsel om at medikamen-

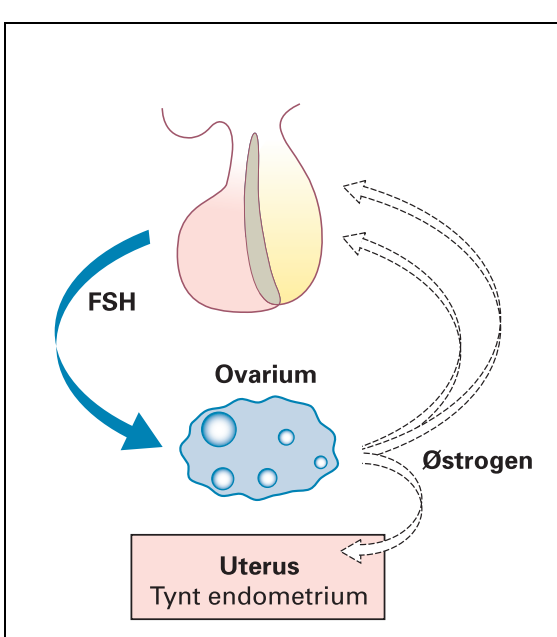

a

Figur 2 Letrozol blokkerer aromatase, et enzym som i eggstokkene katalyserer danningen av østrogener fra androgener. Man får derved lavt østrogennivå, noe som via vanlige tilbakekoblingsmekanismer fremmer økt frigjøring av follikkelstimulerende hormon. Derved vil flere follikler begynne å vokse i første halvdel av follikkelfasen (a). Ettersom letrozol har kort halveringstid på ca. 45 timer, vil østrogenproduksjonen stige i siste halvdel av follikkelfasen (b). Negativ tilbakekobling til hypothalamus og hypofyse vil resultere i redusert utskilling av follikkelstimulerende hormon, noe som gjør at follikler som er mindre enn den dominante follikkelen gjennomgår atresi. Resultatet blir at man får ovulasjon fra én eller to follikler samtidig som man etablerer en normal konsentrasjon av østrogenreseptorer i et tykt endometrium ved ovulasjonstidspunktet 
tet ikke skulle brukes av kvinner som kunne bli gravide eller var gravide. Denne kontraindikasjonen gjelder fortsatt. Verken legemiddelfirmaet som produserer letrozol eller Food and Drug Administration har trukket tilbake sine advarsler. Imidlertid finnes det ingen data som taler for at letrozol slik tablettene benyttes i reproduksjonssammenheng - før eggløsningen - skulle ha teratogen effekt (21).

\section{Ved coitus eller inseminasjon}

Letrozol ser ut til å være et egnet medikament om man ønsker monoovulasjon. Om tablettene anvendes alene, vil typisk én, eller i noen tilfeller to eller tre store follikler utvikles.

I flertallet av hittil publiserte studier er det registrert at ca. $75 \%$ av kvinnene hadde eggløsning ved bruk av letrozol, at endometrietykkelsen ved ovulasjonstidspunket var 7-9 $\mathrm{mm}$ og at graviditetsraten per syklus var $12-25 \%(22,23)$. Man har dessuten vist at letrozol fremkaller ovulasjon hos mer enn $60 \%$ av kvinner som er resistent mot klomifensitrat (22).

\section{Ved in vitro-fertilisering}

Kombinasjonen av letrozol og gonadotropin ser ut til å redusere behovet for gonadotropin (22). Denne kombinasjonen benyttes både ved ovarial stimulering før inseminasjon og ved in vitro-fertilisering. Det mest vanlige er at man behandler med $2,5-5 \mathrm{mg}$ letrozol $\mathrm{i}$ fem dager fra syklusdag 2 eller 3 samtidig som man stimulerer med FSH, eventuelt i kombinasjon med LH.

Aromatasehemmere reduserer negativ tilbakekobling på FSH-sekresjonen og øker ovarienes sensitivitet for FSH (12). Disse mekanismene skulle teoretisk kunne gi en bedre respons ved ovarial stimulering av kvinner med liten ovarial reserve. Så langt har bare noen få relativt små studier blitt publisert når det gjelder behandling av denne pasientgruppen. Noen av disse har konkludert med at letrozol i kombinasjon med FSH gir en bedre ovarial respons enn stimulering med FSH alene hos kvinner med liten ovarial reserve $(24,25)$.

\section{Diskusjon}

Klomifensitrat har vært brukt for ovulasjonsinduksjon i mer enn 40 år. Tablettene er billige (fem tabletter koster drygt 80 kroner). De har dessuten få bivirkninger. Imidlertid er graviditetsfrekvensen ved bruk av klomifensitrat lavere enn forventet dersom man oppnår ovulasjon. Sjansen for graviditet er dessuten størst i de første syklusene. $70-90 \%$ av alle graviditeter skjer i løpet av de tre første stimuleringene. Ifølge Felleskatalogen bør ytterligere kurer ikke forsøkes om man ikke har oppnådd graviditet etter tre ovulatoriske sykluser.

Det har lenge vært ønskelig med perorale legemidler som skulle øke sjansen for monovulasjon og samtidig resultere i en høyere graviditetsfrekvens. Letrozol ser ut til å kunne være et slikt preparat. Tablettene er enkle å svelge og de har få bivirkninger. Forpakninger på fem tabletter selges ikke i Norge, men forpakninger på 30 tabletter, som koster drygt 1200 kroner, er tilgjengelig.

Ettersom letrozol ikke er godkjent for ovulasjonsinduksjon, er det viktig at leger som skriver ut medikamentet til ufrivillig barnløse kvinner, informerer om dette. Før behandlingen starter, bør helst skriftlig samtykke om bruk av tablettene innhentes.

Min egen erfaring er at én tablett daglig i fem dager er tilstrekkelig for å indusere ovulasjon i de fleste tilfeller og at risikoen for ovulasjon fra flere follikler øker om man tar to tabletter daglig. På samme måte som med klomifensitrat bør man derfor alltid starte med én tablett daglig og dessuten utføre ultralyd i preovulatorisk fase for å kontrollere antallet follikler og endometriets tykkelse.

En stor del av kvinnene med anovulasjon lider av polycystisk ovarie-syndrom. Infertile kvinner som tilhører denne pasientgruppen er ofte vanskelig å behandle fordi ovulasjonsinduksjon med klomifensitrat eller FSH medfører økt risiko for flerlinggraviditet samtidig som in vitro-fertilisering er forbundet med fare for utvikling av ovarialt hyperstimuleringssyndrom. Selv om data ikke er entydige, viser de aller fleste studiene at letrozol egner seg godt til denne pasientgruppen (26-28).

Flere studier er imidlertid nødvendig for å vurdere nytteverdien av rutinemessig bruk av letrozol ved in vitro-fertilisering. De studiene som har vært publisert så langt, er for små til at letrozol skal kunne inkluderes som standard i stimuleringsprotokoller. Det finnes imidlertid et par situasjoner der bruk av letrozol kan være gunstig. En av disse er hos unge kvinner med brystkreft, der kvinnene gjennomgår ovarial stimulering etter kirurgisk behandling før en eventuell kjemoterapi $(29,30)$. Man kan derved fryse ned embryoer eller ubefruktede egg med henblikk på å oppnå graviditet på et senere tidspunkt. Ved å stimulere eggstokkene med letrozol i kombinasjon med gonadotropin utsettes kvinnen for østrogennivå som ligger nær de nivåer man har ved ustimulerte sykluser uten at starttidspunktet for en eventuell kjemoterapi blir utsatt. Tilbudet om nedfrysning av ubefruktede egg er ennå ikke etablert i Norge, men utføres rutinemessig ved mange klinikker utenlands. Dessuten kan man forsøke letrozol i kombinasjon med gonadotropin til kvinner som ikke responderer optimalt på maksimaldose med FSH. En pilotstudie konkluderte med at visse kvinner i denne pasientgruppen vil kunne oppnå bedre ovarial respons ved denne kombinasjonsbehandlingen (25). Flere studier er imidlertid nødvendig for å avklare om denne behandlingsstrategien er effektiv.

Klomifensitrat bør fortsatt være førstevalg hos kvinner med anovulasjon, først og fremst på grunn av medikamentets lave inn- kjøpspris og at medikamentet er velkjent blant leger flest. Det er imidlertid viktig å understreke at hos kvinner med spontan ovulasjon vil bruk av klomifensitrat ikke øke sjansen for graviditet (31).

Letrozol kan gis til kvinner som er resistente mot klomifensitrat og kvinner som ikke blir gravide til tross for vellykket ovulasjonsinduksjon med klomifensitrat. Dessuten er letrozol et alternativ til kvinner som responderer på klomifensitrat med danning av for mange store follikler. På den måten kan man minimalisere risikoen for flerlinggraviditet.

Kvinner som anvender letrozol kan ta tablettene hver måned i fem dager i opptil seks måneder, svarende til én forpakning av tablettene. Men det er viktig å individualisere fertilitetsbehandlingen for at den skal bli så optimal og kostnadseffektiv som mulig. Det innebærer blant annet at valg av behandlingsstrategi alltid bør reflektere kvinnens alder, siden reproduktiv alder er den prognostisk viktigste enkeltfaktoren for å oppnå graviditet og fødsel av et friskt barn. I praksis betyr det at i noen tilfeller vil ovulasjonsinduksjon med letrozoltabletter kunne være det rette, mens i andre tilfeller vil in vitrofertilisering være et førstevalg.

Oppgitte interessekonflikter: Ingen

\section{Litteratur}

1. Healy DL, Trounson A, Andersen AN. Female infertility: causes and treatment. Lancet 1994; 343 $1539-44$

2. Rostami-Hodjegan A, Lennard MS, Tucker GT et al. Monitoring plasma concentrations to individualize treatment with clomiphene citrate. Fertil Steril 2004; 81: 1187-93.

3. Homburg R. Clomiphene citrate - end of an era? a mini-review. Hum Reprod 2005: 20: 2043-51.

4. Mitwally MF, Biljan MM, Casper RF. Pregnancy outcome after the use of an aromatase inhibitor for ovarian stimulation. Am J Obstet Gynecol 2005 192: $381-6$

5. Randall JM, Templeton A. Cervical mucus score and in vitro sperm mucus interaction in spontaneous and clomiphene citrate cycles. Fertil Steril 1991; 56: 465-8.

6. Nakamura Y, Ono M, Yoshida Y et al. Effects of clomiphene citrate on the endometrial thickness and echogenic pattern of the endometrium. Fertil Steril 1997; 67: 256-60.

7. Ohno Y, Fujimoto $Y$. Endometrial oestrogen and progesterone receptors and their relationship to sonographic appearance of the endometrium Hum Reprod Update 1998; 4: 560-4.

8. Balen A, Platteau P, Andersen AN et al. Highly purified FSH is as efficacious as recombinant FSH for ovulation induction in women with WHO Group II anovulatory infertility: a randomized controlled non-inferiority trial. Hum Reprod 2007; 22: 1816-23.

9. Kafy S, Tulandi T. New advances in ovulation induction. Curr Opin Obstet Gynecol 2007; 19 248-52.

10. Lamb HM, Adkins JC. Letrozole: a review of its use in postmenopausal women with advanced breast cancer. Drugs 1998: 56: 1125-40.

11. Sioufi A, Sandrenan N, Godbillon J. Comparative bioavailability of letrozole under fed and fasting conditions in 12 healthy subjects after a $25 \mathrm{mg}$ single oral administration. Biopharm Drug Dispos 1997: 18: 489-97.

12. Weil S, Vendola K, Zhou J et al. Androgen and follicle-stimulating hormone interactions in primate ovarian follicle development. J Clin Endocrinol Metab 1999: 84: 2951 -6. 
13. Adashi E. Intraovarian regulation: the proposed role of insulin-like growth factors. Ann NY Acad Sci 1993; 687: 10-2.

14. Casper RF, Mitwally MF. Review: aromatase inhibitors for ovulation induction. J Clin Endocrinol Metab 2006; 91: 760-71.

15. Biljan MM, Hemmings R, Brassard N. The outcome of 150 babies following the treatment with letrozole or letrozole and gonadotropins. Fertil Steril 2005; 84 (suppl 1): S95.

16. Tulandi T, DeCherney AH. Limiting access to letrozole - is it justified? Fertil Steril 2007; 88: 779-80.

17. Tulandi T, Martin J, Al-Fadhli R et al. Congenital malformations among 911 newborns conceived after infertility treatment with letrozole or clomiphene citrate. Fertil Steril 2006; 85: $1761-5$.

18. Shepard TH. Catalog of teratogenic agents. 10 utg. Baltimore, MD: Johns Hopkins University Press, 2001

19. Elizur SE, Tulandi T. Drugs in infertility and fetal safety. Fertil Steril 2008; 89: 1595-602.

20. Tiboni GM, Marotta F, Rossi C et al. Effects of the aromatase inhibitor letrozole on in utero development in rats. Hum Reprod 2008; 23: 1719-23.

21. Gill SK, Moretti M, Koren G. Is the use of letrozole to induce ovulation teratogenic? Can Fam Physician 2008; 54: 353-4.

22. Holzer H, Casper R, Tulandi T. A new era in ovulation induction. Fertil Steril 2006; 85: 277-84.

23. Sh Tehrani Nejad E, Abediasl Z, Rashidi BH et al. Comparison of the efficacy of the aromatase inhibitor letrozole and clomiphene citrate gonadotropins in controlled ovarian hyperstimulation: a prospective, simply randomized, clinical trial. J Assist Reprod Genet 2008; 25: 187-90.

24. Goswamy SK, Das T, Chattopadhyay R et al. A randomized single-blind controlled trial of letrozole as a low-cost IVF protocol in women with poor ovarian response: a preliminary report. Hum Reprod 2004; 19: $2031-5$.

25. Garcia-Velasco JA, Moreno L, Pacheco A et al. The aromatase inhibitor letrozole increases the concentration of intraovarian androgens and improves in vitro fertilization outcome in low responder patients: a pilot study. Fertil Steril 2005; 84: 82-7.

26. Polyzos NP. Tsappi M, Mauri D et al. Aromatase inhibitors for infertility in polycystic ovary syndrome. The beginning or the end of a new era? Fertil Steril 2008; 89: 278-80

27. Badawy A, Mosbah A, Shady M. Anastrozole or letrozole for ovulation induction in clomipheneresistant women with polycystic ovarian syndrome: a prospective randomized trial. Fertil Steril 2008; 89: 1209-12

28. Begum MR, Ferdous J, Begum A et al. Comparison of efficacy of aromatase inhibitor and clomiphene citrate in induction of ovulation in polycystic ovarian syndrome. Fertil Steril 2008; e-publisert 3.1. 2008.

29. Oktay K, Hourvitz A, Sahin G et al. Letrozole reduces estrogen and gonadotropin exposure in women with breast cancer undergoing ovarian stimulation before chemotherapy. J Clin Endocrinol Metab 2006; 91: 3885-90.

30. Azim AA, Costantini-Ferrando M, Oktay K. Safety of fertility preservation by ovarian stimulation with letrozole and gonadotropins in patients with breast cancer: a prospective controlled study. J Clin Oncol 2008; 26: 2630-5.

31. Bhattacharya S, Harrild K, Mollison J et al. Clomiphene citrate or unstimulated intrauterine insemination compared with expectant management for unexplained infertility: pragmatic randomised controlled trial. BMJ 2008; 337: a716. doi: 10.1136/ bmj.a716.

Manuskriptet ble mottatt 13.8. 2008 og godkjent 18.12. 2008. Medisinsk redaktør Trine B. Haugen. 